\title{
BROCCOLI ISOTHIOCYANATE CONTENT AND IN VITRO AVAILABILITY ACCORDING TO VARIETY AND ORIGIN
}

\author{
M. Carmen Rodríguez-Hernández ${ }^{1, \$}$, Sonia Medina ${ }^{2, *}$, Angel Gil-Izquierdo ${ }^{2}$, \\ M. Carmen Martínez-Ballesta ${ }^{1}$, Diego A. Moreno ${ }^{2}$
}

\author{
${ }^{1}$ Plant Nutrition Department, \\ ${ }^{2}$ Food Science and Technology Department, \\ Centro de Edafología y Biología Aplicada del Segura (CEBAS-CSIC), \\ Campus de Espinardo, Edificio 25, E-30100, Murcia, Spain \\ $\$$ These two authors contributed equally to this work \\ dmoreno@cebas.csic.es
}

\begin{abstract}
Broccoli is considered one of the healthiest vegetables due to its high content of beneficial biologically active compounds, i.e. the breakdown products of glucosinolates (GLSs), the isothiocyanates (ITCs). The aim of this work was to characterize the production of ITCs (sulforaphane and iberin and related metabolites) from different sources of GLSs by means of comparison between different broccoli cultivars and commercial samples in terms of their composition and in vitro bioavailability. Differences in the major intact GLSs were observed between the different experimental and commercial samples, showing lower concentrations of GLSs in the latter. The simulation of digestion reduced the concentration of the parent phytochemicals (GLSs), producing via hydrolysis the biologically active ITCs. The commercial samples showed lower levels of ITCs than the experimental broccoli cultivars. Measurement of GLSs by UPLCQqQ-MS/MS allowed for exact quantification of these compounds, particularly ITCs, which will help in future cancer chemoprevention studies.
\end{abstract}

Key words: sulforaphane; iberin; digestibility; maca; isothiocyanates

\section{СОДРЖИНА НА ИЗОТИОЦИЈАНАТИ ВО БРОКУЛА И НИВНА IN VITRO РАСПОЛОЖЛИВОСТ ВО ОДНОС НА ВИД И ПОТЕКЛО}

\begin{abstract}
Брокулата претставува еден од најздравите зеленчуци благодарејќи на високата содржина полезни биолошки активни компоненти, т.е. продукти на разложување на глукозинолати (GLSs), изотиоцијанати (ITCs). Целта на ова истражување беше да се изврши карактеризација на продуктите на ITCs (сулфорафан и иберин и други сродни метаболити) од различни извори на GLSs, со посебен акцент на споредбата на различни култури на брокула и комерцијални примероци од аспект на нивниот состав и in vitro биорасположливост. Разлики во доминантните непроменети GLSs беa забележани помеѓу различните експериментални и комерцијални примероци, покажувајќи пониска концентрација на GLSs кај комерцијалните. Симулацијата на дигестија ја намали концентрацијата на основните фитохемикалии (GLSs), создавајќп со хидролиза биолошко активни ITCs. Комерцијалните култури на брокула покажаа пониско ниво на ITCs во однос на експерименталните. Мерењата на GLSs co UPLC-QqQ-MS/MS овозможија целосна квантификација на овие компоненти, особено на ITCs, што во иднина ќе помогне во хемопревентивните студии за рак.
\end{abstract}




\section{INTRODUCTION}

Epidemiological studies have shown that a diet rich in fruits and vegetables such as cruciferous foods may reduce the risk of many cancers [1-2]. In particular, cruciferous vegetables may provide greater protective benefits than many other vegetables or fruits [2]. Broccoli, the globally known immature flower vegetable of Brassicaceae (Brassica oleracea L. [Italica group]), is well-recognized as a health promoter owing to its high content of beneficial biologically active compounds [3], is rich in antioxidants which may play important roles in chemoprevention [4]. In addition to these compounds, shared with many other plant foods, broccoli contains glucosinolates (GLSs), which are considered to play the major role in health protection and the reduction of cancer risk by crucifers [5].

GLSs are a unique group of sulfur-containing plant secondary metabolites that require enzymatic hydrolysis by myrosinase, a $\beta$-thioglucosidase present only in the plant and in the gut microflora, to form various metabolites [6] such as glucose, hydrogen sulfate, thiocyanates, nitriles or isothiocyanates (ITCs), depending on the starting glucosinolate, reaction $\mathrm{pH}$ and availability of transition metal ions [7-8].

ITCs are the bioactive compounds of cruciferous foods [4, 9-10]. A large body of available data clearly demonstrates that ITCs are effective inhibitors of carcinogenesis [11]. Sulforaphane (1-isothiocyanate4-(methylsulfinyl)-butane, SFN), derived from glucoraphanin (GR), and iberin (1-isothiocyanate-3-(methylsulfinyl)-propane, IB) derived from GIB, are major ITCs in broccoli, derived from methylsulfinyl GLSs which are found in high concentrations in broccoli heads or inflorescences $[12,13]$, as well as in the germinating seeds and edible sprouts of broccoli of the green and purple varieties [14]. After ingestion, ITCs are metabolized by the mercapturic acid pathway and are ultimately excreted in the urine, predominantly as $N$-acetyl-cysteine con- jugates, as demonstrated for SFN [6]. However, little information is available about the variation in production of broccoli ITCs (SFN and IB) and other metabolites of GLS degradation according to agronomical (genotypes, geographical origins) or physiological (organs) factors. Moreover, the study of the selection of different varieties of brassica sprouts and the measurement of their phytochemical composition is a valuable tool for the development of new fresh functional foods containing healthpromoting compounds $[15,16]$.

The differential production of these metabolites may also result in changes during absorption and metabolism in the animal/human body. For this reason, the aim of this work was to characterize the production of broccoli ITCs (SFN and IB, and related metabolites) from different sources of GLSs by means of comparison between different samples from broccoli organs and commercial ingredient sources, in terms of their composition, in vitro availability, bioaccesibility and metabolism.

\section{MATERIALS AND METHODS}

\subsection{Plant material sourcing and growth conditions}

Broccoli plants. Two varieties of broccoli (Brassica oleracea L. [Italica group]), a purple-sprouting broccoli ('Viola', Thompson \& Morgan Ltd., Cedar Lane, Ipswich, UK) and a green-sprouting broccoli ('Naxos', Sakata Seed Ibérica S.L., Valencia, Spain), were grown in an experimental field (latitude $38^{\circ} 06^{\prime} \mathrm{N} ; 1^{\circ} 02^{\prime} \mathrm{W}$ ) in a semi-arid Mediterranean climate in the winter season at La Matanza (Santomera, Murcia, SE Spain). First, broccoli seeds were prehydrated and germinated in vermiculite $\left(28^{\circ} \mathrm{C}\right.$ in the dark) for 3 days. Then, seedlings were transferred to a controlled-environment growth chamber with a $16 \mathrm{~h}$ light $-8 \mathrm{~h}$ dark cycle and air temperature of 25 and $18^{\circ} \mathrm{C}$, respectively. The relative humidity $(\mathrm{RH})$ was $60 \%$ (day) and $80 \%$ (night), and the photosynthetically active radiation (PAR) was $400 \mu \mathrm{mol} \mathrm{m} \mathrm{m}^{-2} \mathrm{~s}^{-1}$, 
provided by a combination of 44 fluorescent tubes (Philips TLD $36 \mathrm{~W} / 83$ and Sylvania F36 W/GRO) for every two metal halide lamps (Osram HQI.T $400 \mathrm{~W}$ ). After 4 days, the seedlings were transplanted to hydroponic containers (15 liters) filled with Hoagland nutrient solution, which was completely replaced every week. After 24 days (days after transplanting (DAT) $=0$ ), plants were transplanted to open-air cultivation and the same solution was used for irrigation. Daily mean temperature and relative humidity $(\mathrm{RH})$ in the open-air cultivation were calculated from measurements taken every 30 min using dataloggers (AFORA SA, Barloworld Scientific, Murcia, Spain). The temperature range was $2-10^{\circ} \mathrm{C}$ (minimum) and 18 $20^{\circ} \mathrm{C}$ (maximum), the $\mathrm{RH}$ range was $70-100 \%$ (maximum) and 20-40\% (minimum) and the PAR was $1000 \mu \mathrm{mol} \mathrm{m}^{-2} \mathrm{~s}^{-1}$ during the first 43 DAT with reductions until $500 \mu \mathrm{mol} \mathrm{m}{ }^{-2} \mathrm{~s}^{-1}$ at 44 DAT followed by an increase to $1500 \mu \mathrm{mol}$ $\mathrm{m}^{-2} \mathrm{~s}^{-1}$ at 72 DAT. A total of 20 broccoli plants were placed in a randomized design, using 10 plants per cultivar, resulting in a density of two plants $\mathrm{m}^{-2}$. All the plants were sampled at 95 DAT ( $\sim 120$-day old plants) by collecting whole aerial biomass (stalks, leaves and inflorescences). After recording the weight, samples were flash-frozen using liquid nitrogen and kept at $-80^{\circ} \mathrm{C}$ until being freeze-dried (Christ Alpha 1-4D, Christ, Osterode am Harz, Germany). The material was ground into a fine powder and stored at $-20^{\circ} \mathrm{C}$ for further analysis.

Edible sprouts. Edible sprouts of 'Naxos' and 'Viola' broccolis were obtained from prehydrated and germinated seeds in cellulose trays kept for 8 days in a controlled-environment growth chamber, with a $16 \mathrm{~h} / 8 \mathrm{~h}$ light/dark cycle, air temperature $25 / 18^{\circ} \mathrm{C}$ and relative humidity $(\mathrm{RH}) 60 \% / 80 \%$. Photosynthetically active radiation (PAR, $400 \mu \mathrm{mol} \mathrm{m}^{-2} \mathrm{~s}^{-1}$ ), was provided by a combination of fluorescent tubes (Philips TLD 36 W/83 and Sylvania F36 W/GRO) and metal halide lamps (Osram HQI.T $400 \mathrm{~W}$ ). The edible sprouts and seed samples were then flashfrozen using liquid nitrogen and kept at $-80^{\circ} \mathrm{C}$ until being freeze-dried (Christ Alpha 1-4D,
Christ, Osterode am Harz, Germany). Samples were ground to a fine powder and stored at $-20^{\circ} \mathrm{C}$ until further analysis.

Broccoli commercial samples. Powdered broccoli from AQP\&Ingredients SL (Murcia, Spain) and Draco (Draco Natural Products, Inc., Broccoli powdered extract, San Jose, California, USA) were used to compare with the experimental samples.

Alternative source of GLSs. In order to use a sample without glucoraphanin (SFN parental-GLS) or GIB (IB parental-GLS), commercial powders of Lepidium campestre L., namely 'Energy-Mac', 'Harina', and naturally produced maca (from a local grower) (Lima, Peru) were integrated into the experiment.

\subsection{In vitro gastrointestinal digestion}

This method allows for investigating the release of GLSs and ITCs and to study their behavior and stability upon simulated gastrointestinal conditions. The experiment consisted of pepsin- $\mathrm{HCl}$ digestion for $2 \mathrm{~h}$ and pancreatic digestion with bile salts for $2.5 \mathrm{~h}$, both at 37 ${ }^{\circ} \mathrm{C}$. For the pepsin- $\mathrm{HCl}$ digestion, the sample $(60 \mathrm{ml})$ was treated with 15,750 units of pepsin (EC 3.423.1; Sigma, Steinheim, Germany). The $\mathrm{pH}$ was adjusted to 2 , and the samples were incubated in a $37^{\circ} \mathrm{C}$ shaking water bath (Selecta, Barcelona, Spain). The pepsin digests $(20 \mathrm{ml})$ was transferred to a polyethylene tube containing cellulose dialysis tubing (molecular weight cut-off of $12000 \mathrm{Da}$; Sigma) filled with $25 \mathrm{ml}$ of water and the amount of $\mathrm{NaHCO}_{3}$ (Sigma) equivalent to the titratable acidity (equivalents of $\mathrm{NaHCO}_{3}$ required to titrate the combined pepsin-digest pancreatin-bile extract mixture to $\mathrm{pH}$ 7.5) [17]. Five milliliters of pancreatinbile extract mixture was added when the $\mathrm{pH}$ value reached 5.0 and was left for $2 \mathrm{~h}$ to allow for enzyme activity and to reach an equilibrium between the dialyzed (permeate) and nondialyzed (retentate) fractions [17]. GLSs were analyzed by HPLC-DAD and ITCs were analyzed by UPLC-MS/MS (Agilent technologies, Waldbronn, Germany). 


\subsection{Analysis of GLSS}

Undigested samples and samples of the in vitro gastrointestinal digestion, i.e. samples of the both dialyzed (permeate) and non-dialyzed (retentate) fractions $(20 \mu \mathrm{l})$ were analyzed in a Waters HPLC-DAD system (Waters Cromatografía S.A., Barcelona, Spain) consisting of a W600E multisolvent delivery system, in-line degasser, W717 plus autosampler and a W2996 photodiode array detector at $330 \mathrm{~nm}$. The compounds were separated on a Luna $\mathrm{C} 18$ column $(25 \mathrm{~cm} \times 0.46 \mathrm{~cm}, 5 \mu \mathrm{m}$ particle size; Phenomenex, Macclesfield, UK) with a security guard C18-ODS $(4 \times 30 \mathrm{~mm})$ cartridge system (Phenomenex). The mobile phase was a mixture of water/trifluoroacetic acid (99.9:0.1, V/V) (A) and a mixture of acetonitrile/trifluoroacetic acid (99.9:0.1, V/V) (B). The flow rate was $1 \mathrm{ml} \mathrm{min}{ }^{-1}$ in a linear gradient, starting with $1 \% \mathrm{~B}$ for $5 \mathrm{~min}$ to reach $17 \% \mathrm{~B}$ at $15 \mathrm{~min}$ and maintained for 2 min, $25 \% \mathrm{~B}$ at $22 \mathrm{~min}, 35 \% \mathrm{~B}$ at $30 \mathrm{~min}, 50 \%$ $\mathrm{B}$ at $35 \mathrm{~min}$ and $99 \% \mathrm{~B}$ at $40 \mathrm{~min}$.

GLSs $(227 \mathrm{~nm})$ were eluted off the column at $35 \mathrm{~min}$, identified using a previously described LC-MS method [18] and quantified using sinigrin as the standard (sinigrin monohydrate from Sinapis nigra, Phytoplan Diehm \& Neuberger, Gmbh, Heidelberg, Germany). The content of GLSs was expressed as milligrams per $100 \mathrm{~g}$ of fresh weight.

\subsection{Analysis of ITCs}

After in vitro gastrointestinal digestion, samples of the both dialyzed (permeate) and non-dialyzed (retentate) fractions, as well as the undigested samples, were analyzed by UPLCMS/MS (UPLC-1290 Series and a 6460 QqQMS/MS; Agilent Technologies, Waldbronn, Germany). Chromatographic separation was carried out on a ZORBAX Eclipse Plus C18 column $(2.1 \times 50 \mathrm{~mm}, 1.8 \mu \mathrm{m})($ Agilent Technologies, Waldrom, Germany). The column temperature was held at $10^{\circ} \mathrm{C}$ (left and right). The Multiple Reaction Monitoring (MRM) was performed using positive ESI mode and the dwell time was $25 \mathrm{~ms}$ for all MRM transitions. The MS analysis was applied in MRM mode, assigning preferential MRM transition of the corresponding analytes. The mobile phases employed were solvent $\mathrm{A}\left(\mathrm{H}_{2} \mathrm{O} / \mathrm{ammo}-\right.$ nium acetate $13 \mathrm{mM}(\mathrm{pH} 4)$ (with acetic acid); 99.99:0.01, V/V) and solvent B (ACN/acetic acid; 99.99:0.1, V/V). The flow rate was $0.3 \mathrm{ml}$ $\min ^{-1}$ using a linear gradient scheme $(\mathrm{t} ; \% \mathrm{~B})$ : $(0.00 ; 60),(7.00 ; 60),(7.01 ; 73),(10.00 ; 73)$, $(10.01 ; 100),(13.50 ; 100)$, and $(13.51 ; 60)$.

T a b l e 1

Optimized dynamic MRM conditions for the analysis of the studied compounds and their metabolites by UPLC-QqQ-MS/MS

\begin{tabular}{ccccc}
\hline \hline Analyte & MRM $(\mathrm{m} / \mathrm{z})$ & Fragmentor $(\mathrm{V})$ & $\mathrm{CE}^{\mathrm{b}}(\mathrm{V})$ & Retention time $(\mathrm{min})$ \\
\hline $\mathrm{GR}^{a}$ & $438>196$ & 90 & 4 & 0.8 \\
SFN & $178>114$ & 70 & 4 & 1.6 \\
SFN-CYS & $299>178$ & 115 & 0 & 0.9 \\
SFN-NAC & $341>178$ & 80 & 0 & 2.2 \\
SFN-GSH & $485>178$ & 80 & 0 & 0.9 \\
GIB & $421.9>357.7$ & 100 & 0 & 2.2 \\
IB & $164>105$ & 90 & 6 & 1.4 \\
\hline \hline
\end{tabular}

${ }^{a}$ Analyzed compounds, GR: glucoraphanin, SFN: sulforaphane, SFN-Cys: sulforaphane-cysteine,

SFN-NAC: sulforaphane-N-acetylcysteine, SFN-GSH: sulforaphane-gluthatione, GIB: glucoiberin, IB: iberin.

${ }^{b} \mathrm{CE}$ : collision energy. 
The optimal ESI conditions for maximal detection of the analytes were: gas flow: $81 \mathrm{~min}^{-1}$, nebulizer: 30 psi, capillary voltage: $2750 \mathrm{~V}$, nozzle voltage: $1500 \mathrm{~V}$, gas temperature: $325^{\circ} \mathrm{C}$, sheath gas temperature: $350^{\circ} \mathrm{C}$, and jet stream gas flow: $121 \mathrm{~min}^{-1}$. The acquisition time was 13.5 min for each sample with a post-run of $1.5 \mathrm{~min}$ for the column equilibration. The MS parameter fragmentor (ion optics capillary exit voltage) and collision energy were optimized for each compound to generate the most abundant product ions in MRM mode. Selected reaction monitoring (SRM) MS/MS transitions were developed for the analytes using collision induced dissociation (CID) (Table 1). The MRM of the all compounds were measured using positive ESI mode, except for GIB which was quantified in negative ESI mode. Data acquisition was performed using MassHunter software version B.04.00 (Agilent, Waldrom, Germany).

GR was a gift from Professor Dr. Renato Iori (CRA-CIN, Rome, Italy). SFN was purchased from Sigma (St. Louis, MO, USA), and the standards SFN-gluthatione, SFN-cysteine and SFN-N-acetylcysteine (SFN-GSH, SFNCys and SFN-NAC, respectively) were from purchased Santa Cruz Biotech (Santa Cruz, CA, USA). GIB was purchased from Phytoplan Diehm \& Neuberger Gmbh (Heidelberg, Germany) and IB from LKT Laboratories (Biomol Gmbh, Hamburg, Germany).

\section{RESULTS AND DISCUSSION}

The HPLC-DAD system was used to quantify the major intact GLSs in the different plant samples (Brassica oleracea - broccoli, and Lepidium spp. - maca); the results are shown in Figures 1, 2 and 3.

The initial sample is the extract of nonprocessed/digested samples, collected before in vitro digestion at $37^{\circ} \mathrm{C}$. The samples collected at the end of digestion, from inside and outside the cellulose-dialysis membrane, were analyzed for GLSs and ITCs in the dialyzed (permeate) and non-dialyzed (retained) fractions, respectively. Furthermore, as stated before, Table 1 shows the optimized dynamic MRM conditions for the analysis of the studied compounds (Figure 4), which were formed under gastrointestinal conditions in vitro. Thus, differences between the compounds (GR, SFN and SFN compounds, GIB and IB) were observed.

The results in Figure 1 to 3 show that intact aliphatic GLSs (GIB, glucoerucin, and progoitrin) and indolic GLSs (glucobrassicin, 4-MeO-glucobrassicin, 4-OH-glucobrassicin, neoglucobrassicin) were identified and quantified in extracts of broccoli cultivars and organs and in the commercial broccoli and maca samples (Figs. 1 and 2).

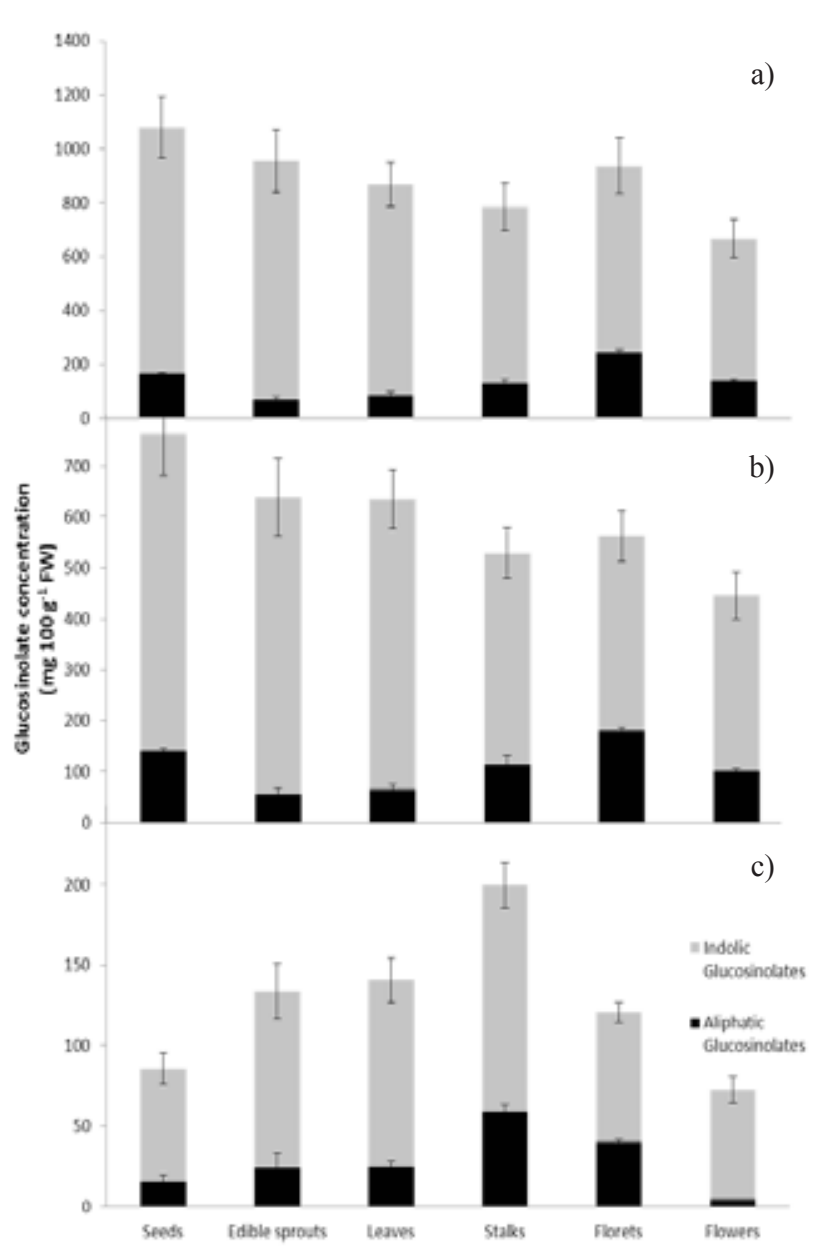

Fig. 1. Aliphatic (glucoiberin, glucoerucin) and indolic (glucobrassicin, 4-MeO-glucobrassicin, 4-OH-glucobrassicin, neoglucobrassicin) glucosinolates (mg $100 \mathrm{~g}^{-1} \mathrm{FW}$ ) in green-sprouting broccoli samples of cv. 'Naxos'. Undigested, (initial, a), dialyzed (permeate, b) and non-dialyzed (retentate, c) fractions of the in vitro digestion ( $n=4$ for each sample) 


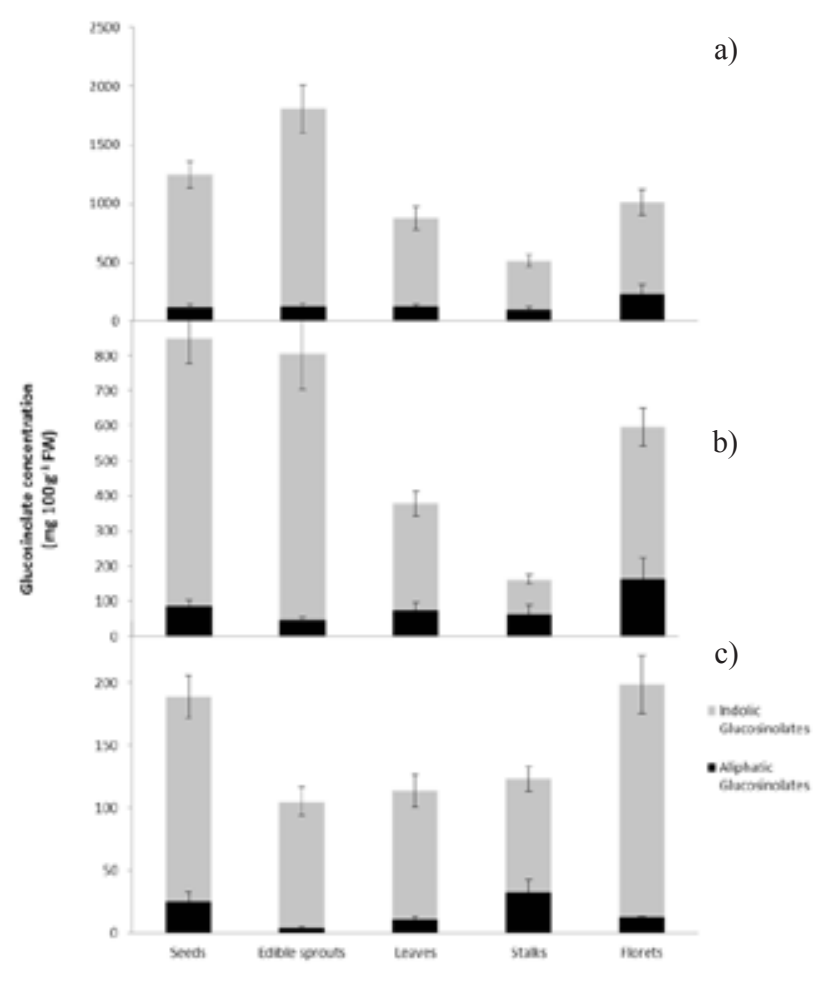

Fig. 2. Aliphatic (glucoiberin, glucoerucin) and indolic (glucobrassicin, 4-MeO-glucobrassicin, 4-OH-glucobrassicin, neoglucobrassicin) glucosinolates (mg $100 \mathrm{~g}^{-1}$ FW) in purple-sprouting broccoli samples of cv. 'Viola'. Undigested (initial, a), dialyzed (permeate, b), and nondialyzed (retentate, $c$ ) fractions of the in vitro digestion ( $n=4$ for each sample)

The 'Naxos' cultivar had higher total glucosinolate concentrations (Figure 1a) in initial samples (undigested) and a relatively lower concentration in the dialyzed samples. The non-dialyzed fraction for all the organs was the smallest. In the initial samples, there were quantitative differences between organs, with the seeds and the florets richer in aliphatic GLSs, while sprouts and leaves showed lower values. Indolic GLSs were higher in the seeds than in the remaining organs, and seeds were the main source of total GLSs. The flowers showed both the lowest indolic and total GLS levels. In dialyzed samples of cv. 'Naxos' (Figure 1b), the highest value of aliphatic GLSs was found in the florets (with a decrease of $26 \%$ with respect to the initial sample) and

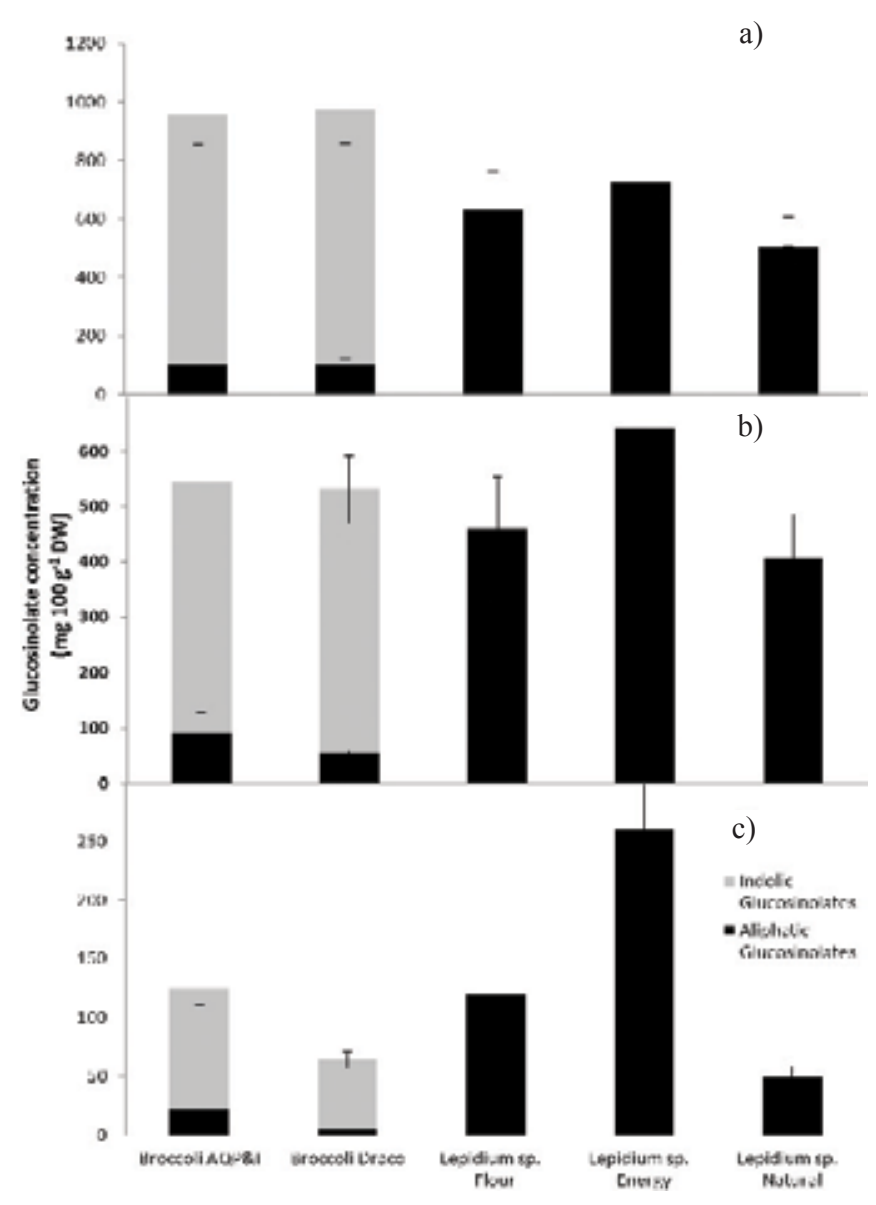

Fig. 3. Aliphatic (glucoiberin, glucoerucin) and indolic (glucobrassicin, 4-MeO-glucobrassicin, 4-OH-glucobrassicin, neoglucobrassicin) glucosinolates (mg $100 \mathrm{~g}^{-1}$ DW) in different commercial broccoli samples. For the Lepidium sp. (maca flour), the bars represent benzyl-glucosinolate (glucotropaeolin and derivatives). Undigested (initial, a), dialyzed (permeate, b) and non-dialyzed (retentate, $c)$ fractions of the in vitro digestion ( $n=4$ for each sample).

the lowest concentration in the sprouts (a 20 $\%$ decrease). The highest concentration of indolic GLSs was quantified in the seeds (a decrease of $32 \%$ ) and the lowest was found in flowers (a decrease of $35 \%$ ). In non-dialyzed samples of cv. 'Naxos' (Figure 1c), we observed higher aliphatic and indolic GLSs in stalks and lower contents in flowers (by a 75 $\%$ and $88 \%$ decrease, respectively, from the initial samples).

In Figure 2, results from the purple sprouting broccoli 'Viola' are shown. Similarly, the 

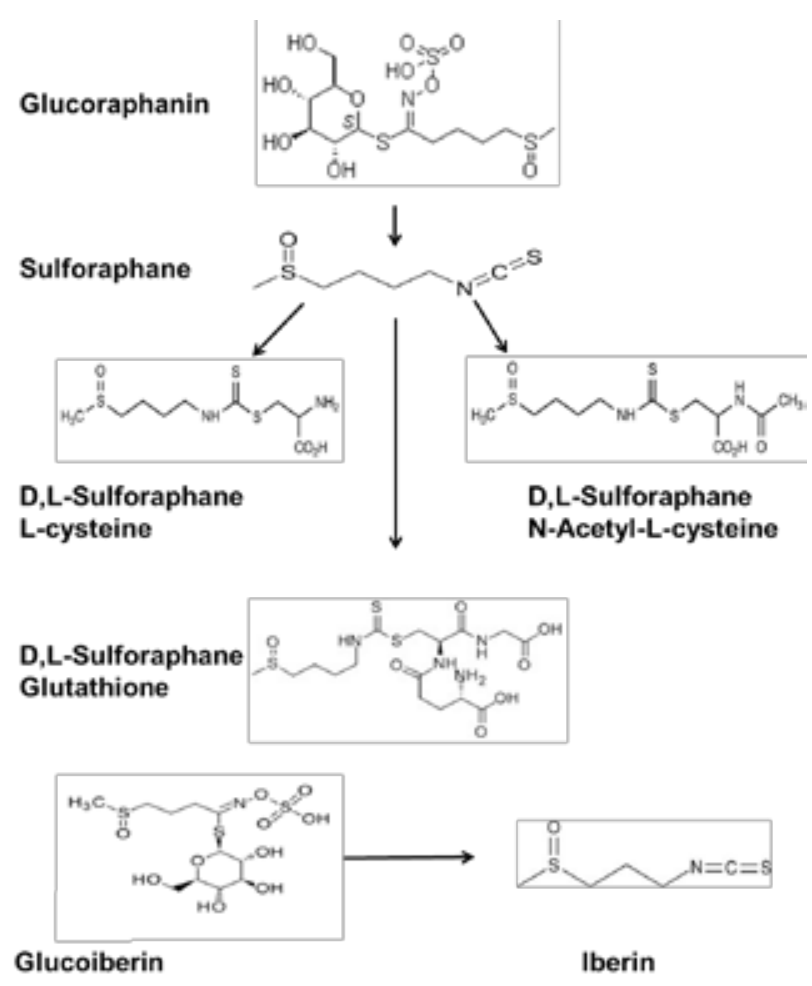

Fig. 4. Structure of the analyzed compounds by UPLC-QqQ-MS/MS

highest GLS concentrations were also found in the initial samples, followed by the concentrations found in the dialyzed samples, and finally in the non-dialyzed samples. The undigested initial samples (Figure 2a) showed the highest aliphatic GLS concentrations in the florets, and the indolic GLSs were found at higher concentrations in the sprouts. The lowest values obtained for all the GLSs were found in the stalks. For the dialyzed samples (Figure 2b), the aliphatic GLS concentration was again highest in florets and lowest in the sprouts $(29 \%$ and $62 \%$ less than in the initial samples, respectively), while for the indolic GLSs, the highest concentrations were retained in the seeds and the lowest were found in the stalks (32\% and $76 \%$ less than in the initial samples, respectively), similar to what was found for total GLSs. In non-dialyzed samples (Figure 2c), the highest concentrations of aliphatic GLSs was retained in stalks (67\% less than in the initial samples), and the lowest was found in the sprouts (97\% less than in the initial samples). For indole GLSs, the highest concentrations were observed in florets and the lowest were found in the stalks (76 $\%$ and $78 \%$ less than in the initial samples, respectively). Also, the total GLS concentration in non-dialyzed samples was highest in florets ( $80 \%$ less than in the initial samples) and lowest in sprouts (with $94 \%$ less than in the initial samples).

In the commercial samples (Figure 3), the same trend was found, with higher GLS concentrations in the initial samples, followed by the dialyzed and non-dialyzed samples for both samples. For commercial broccoli, the values obtained were similar between both sources in the initial samples (Figure $3 a$ ). In the dialyzed samples (Figure 3b), the concentration of aliphatic GLSs was higher in AQP\&I than in the Draco samples, and they showed a reduction of $14 \%$ and $48 \%$ respectively. For the indolic GLSs, the reductions were similar (by $47 \%$ in AQP\&I and by $45 \%$ in Draco, from the starting concentration). For non-dialyzed samples (Figure 3c), the GLSs were greatly reduced and again higher in the AQP\&I-broccoli powder than in the Draco extract samples ( $86 \%$ and $92 \%$ less GLSs than in the initial samples, respectively).

In maca (Lepidium sp.) samples (Figure $3)$, there were no indolic GLSs found. Furthermore, only benzyl glucosinolate and its derivatives were found. There was certain variability between Lepidium sp. samples as follows: 'Energy' > 'Flour' > 'Natural'. The dialyzed samples were similar in the differences among origins (with a decrease of $27 \%$ in Flour, 12 $\%$ in Energy and $20 \%$ in Natural) as well as in the non-dialyzed samples (with a decrease of $81 \%$ in Flour, $64 \%$ in Energy and $90 \%$ in Natural).

Comparing the results of broccoli plants and organs (Figure 1 and 2) and the commercial sources (Figure 3), cv. 'Naxos' showed relatively higher concentrations of aliphatic GLSs in the seeds and florets in the initial and 
dialyzed samples, whereas the stalks showed the highest content in the non-dialyzed samples. In cv. 'Viola', the organ influence was different, with higher concentration of aliphatic GLSs in the florets and seeds for the initial and dialyzed samples, but similar to what happened in green 'Naxos' broccoli, the stalks retained the highest levels of aliphatic GLSs in the non-dialyzed fraction. For the commercial samples, initial and dialyzed samples showed much lower concentrations of GLSs than the experimental broccoli samples.

The samples of Lepidium sp. were higher in total GLSs than the commercial broccoli samples for the dialyzed and non-dialyzed samples, but not in the undigested starting material. However, for the maca samples, GLSs were represented only by benzyl-GLS (glucotropaeolin), not glucoiberin (GIB), glucoerucin (GE) or glucoraphanin (GR).

The concentration of GLSs, mainly aliphatic GLSs, varies widely among different developmental stages of the plant, and also among different organs [19-21]. Also, aliphatic GLSs are clearly regulated by genotype; in contrast, the effects of environment and genotype $\times$ environment interactions on the indolic GLS content appeared to be the main effects of variation [22]. The differences found between green and purple broccoli cultivars or between broccoli and maca samples agreed with this. Furthermore, processing prior to analysis could also affect GLSs, such as occurred in maca samples, which is in agreement with others reports [23].

Climatic conditions and ecophysiological factors, such as temperature and radiation, relative humidity and the degree of hydration, have an influential role on the phytochemical content of vegetables [24, 25]. Thus, Brown et al. [26] evaluated a subset of 10 broccoli varieties grown over four seasons, which allowed for determining the extent to which the GLS content varies with genotype and with environmental conditions [27]. Charron et al. [28] also found variations in the glucosi- nolate content in cabbage leaves harvested in the spring and fall seasons; the highest concentrations of total GLSs generally occurred when crops were harvested during periods of high temperature and long day length. Also, sprouts of most broccoli cultivars studied in recent years contain GR as the main thiofunctionalized glucosinolate, with its concentration dependent on genotype and the duration of the sprouting period [23]. Oliviero et al. [29] showed that glucosinolate degradation increased with temperature. In our case, we showed a higher amount of GLSs in the original sample of plant material before in vitro digestion.

Should be noted that simulated digestion is far less complex than an animal feeding study, and a variety of factors could affect recovery in vivo, such as absorption of intact GLSs [30]. Thus, in this work, simulated digestion using major enzymes such as $\alpha$-amylase, gastric pepsin and intestinal pancreatin induced the differences found for the concentration of GLSs in the different steps of in vitro digestion.

Existing methods to extract and prepare ITCs from biological samples are often complicated and time-consuming [31]. However, Dominguez-Perles et al. [32] developed a quantitative method for the direct determination of intact ITCs in plant and other biological samples. Thus, ITCs were detected before and after the in vitro digestion of plant samples of different origins. We used UPLC-MS triple quadrupole technology to simultaneously analyze SFN, IB and their mercapto-conjugates in a single injection (Table 2). The 'Naxos' cultivar showed higher GR concentrations in the initial samples for all the organs, except for the leaves and flowers, where GR was not detected. For the dialyzed samples, GR was only detected in seeds and, finally, in the non-dialyzed fractions, GR was absent. With respect to the SFN concentration, cv. 'Naxos' showed a similar trend for SFN contents in all organs: initial $>$ dialyzed $>$ non-dialyzed samples. 
For the ITC metabolites studied, SFNCYS was present in undigested samples. The dialyzed and non-dialyzed samples presented SFN-CYS in the seeds, sprouts and flowers. SFN-NAC was detected in all the 'Naxos' organs in the initial samples, and was only present in seeds, leaves and flowers in the dialyzed samples and absent in almost all the non-dialyzed samples, detected only in flowers. SFNGSH was detected only in seeds, sprouts and stalks in the initial samples, and present only in the dialyzed samples from seeds. In relation to GIB, the concentrations found in the different organs were much higher in the initial samples, except in seeds which showed no GIB, followed by the dialyzed samples and, finally, the non-dialyzed samples. Finally, the IB concentration was very low in the initial undigested samples of cv. 'Naxos' and very low levels (not quantifiable) were found in the dialyzed and non-dialyzed samples.

For the samples of 'Viola' broccoli (Table 2), the extracts of undigested material showed GR, except for the leaves. There was a great reduction in the content in the dialyzed samples, and GR was only detected in florets. Moreover, GR was absent in the non-dialyzed samples. For the SFN concentrations in undigested 'Viola' samples, all organs presented SFN in higher concentrations than GR. For the dialyzed samples, the SFN content was reduced and lower levels were also detected in the nondialyzed samples. When analyzing SFN metabolites in these 'Viola' samples, the SFN-CYS concentration was higher in the initial samples, except in both leaves and stalks where it was not detected. The dialyzed and non-dialyzed samples did not show any SFN-CYS. A similar situation was found for SFN-NAC, with low concentrations in the initial samples, and with detection only in the leaves, stalks and florets of the dialyzed samples and in the florets of the non-dialyzed samples. SFN-GSH was detected only in the seeds of undigested samples of 'Viola', as in 'Naxos'. GIB was found at a much higher concentration in 'Viola' samples than in 'Naxos' for the undigested samples, as expected and also seen in literature [14, 33]. A very high proportion of GIB passed the membrane and was detected in the dialyzed fraction, and only a small amount of GIB remained in the non-dialyzed fraction. For IB, the content was also much higher in 'Viola' than in 'Naxos' samples, and again, a lower proportion was detected in the dialyzed samples, and scarce levels in the non-dialyzed samples. Looking into the commercial broccoli samples, for GR and GIB and their respective ITCs and related metabolites (Table 2), we only found GR, SFN and GIB in the AQP\&I broccoli powder, with only SFN and GIB in the dialyzed extract, whereas the Draco broccoli presented a low amount of SFN and SFN-CYS, but a higher level of GIB. Similarly, only SFN and GIB were present in the dialyzed extracts and only GIB was found in the non-dialyzed extracts.

The Lepidium sp. (maca commercial flours) samples were analyzed for these GLSs and ITCs. Since benzyl-GLS and its cognate BITC were not available for setting the experiments in the UPLC-QqQ-MS study, and since the presence of GR (SFN and metabolites) or GIB (IB) was not expected, the results are not shown.

Taking all the data on the GLSs, GR and GIB and their hydrolysis products, we can say that cv. 'Naxos' showed higher ITC levels in all the tested samples. Both commercial broccolis had a very low level of ITCs or related metabolites.

The GLSs are hydrolyzed by the enzyme myrosinase into a range of breakdown products such as thiocyanates, ITCs and nitriles [34-35]. In the gastrointestinal tract, the GLSs are hydrolyzed by bacteria during digestion [36], but at a lower rate than in plant systems. ITCs must be absorbed to exert their associated cancerpreventive activity [37]. For this reason, the non-dialyzed fraction showed the lowest values of GLSs and ITCs and their derivatives/ metabolites, suggesting that the amount of GLSs or ITCs discarded was minimal, showing 


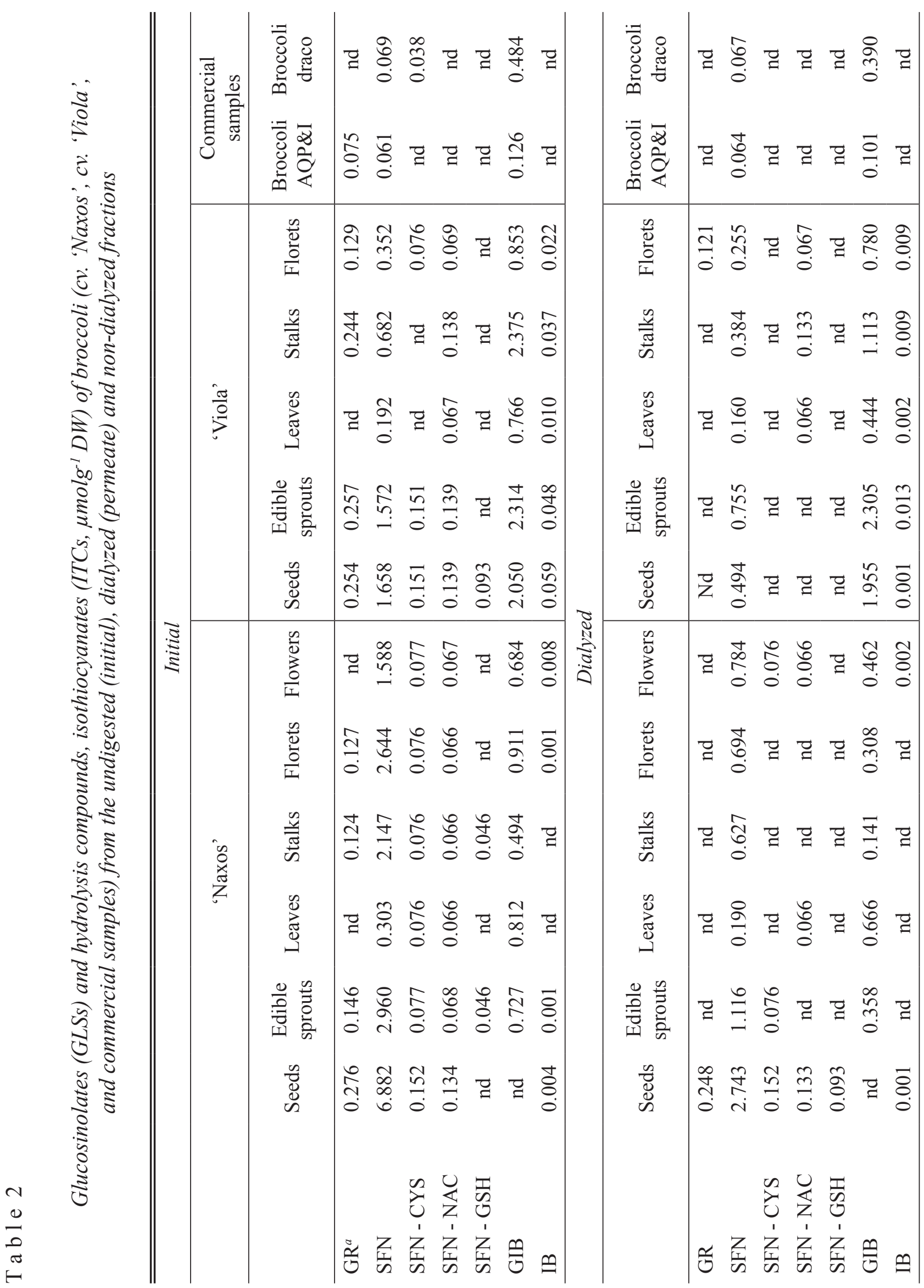




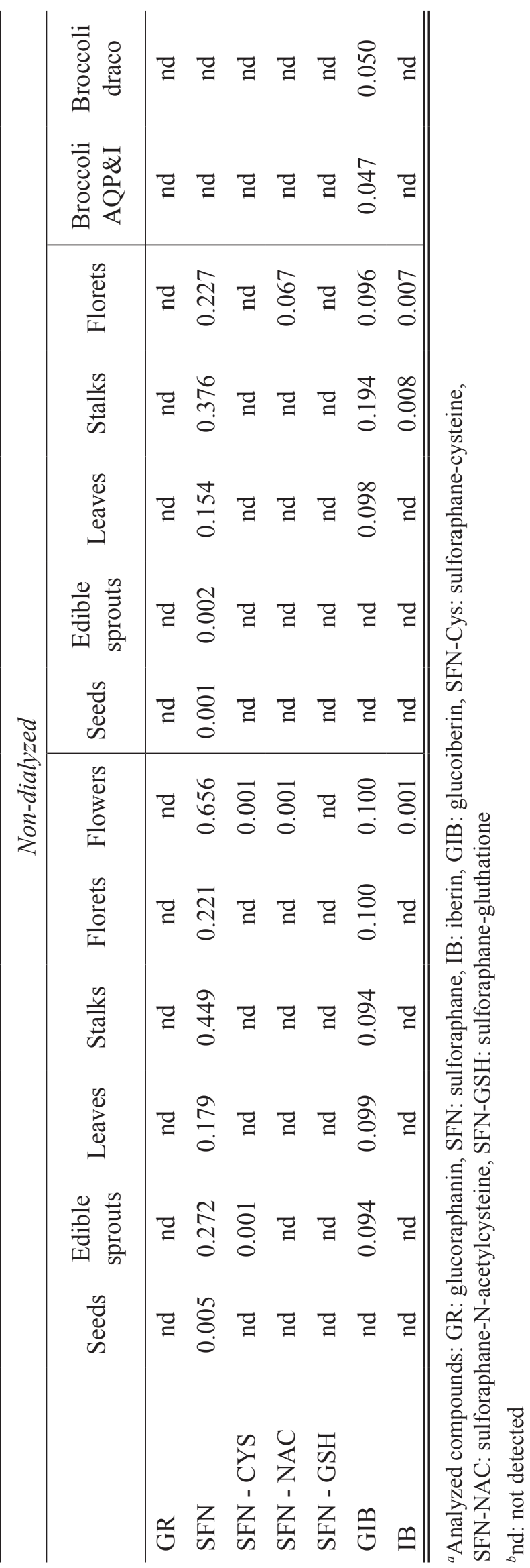

the high bioaccesibility and liberation of these compounds under gastrointestinal conditions from the original plant tissue. Also, the results obtained from the permeate (dialyzed) fraction indicated that a major part of these ingested compounds may be ready to be absorbed. Therefore, ITCs and their naturally occurring glucosinolate precursors are consumed as part of a diet rich in cruciferous vegetables such as broccoli [38]. Moreover, both GLSs and ITCs were expressed at higher concentrations in the initial undigested samples.

ITCs are metabolized primarily through the mercapturic acid pathway [2]. There is growing evidence that metabolites generated via the mercapturic acid pathway can contribute to the biological activity of dietary ITCs, such as SFN [39]. ITC metabolites can be measured in the urine, and are highly correlated with dietary intake of cruciferous vegetables [40]. In this work, in vitro digestion allowed the analysis of ITCs in different steps of the digestion process; the data show a decrease in the ITC concentrations throughout the digestion process.

Cramer et al. [41] showed that sources of myrosinase can enhance the conversion of GR to SFN. In this work, in vitro digestion led to the hydrolysis of GR to SFN and/or SFN derivatives (Table 2). In this sense, it should be noted that in some cases, SFN was synthesized in vitro, suggesting that the enzymes utilized in this model are implicated in the formation of SFN and their conjugates. Thus, under these in vitro digestion conditions, myrosinase activity could be also favored. The measurement of SFN metabolites in broccoli has been a useful tool for assessing human exposure to SFN, a compound associated with a reduced risk of cancer [9]. SFN metabolites in plasma reflect the amount of SFN that tissues are being exposed to and are therefore important biomarkers of exposure to this cancer-preventive agent [41]. In this study, we showed that cv. 'Naxos' was the broccoli source with the highest amounts for all the studied ITCs and metabolites in a number of organs and fractions (i.e., seeds, edible sprouts, and florets). On the other hand, the in vitro di- 
gestion showed that the 'Viola' broccoli had a higher concentration of the glucosinolate GIB than its breakdown product IB due to the high level of this glucosinolate in this cultivar [33]. However, Lepidium sp. samples showed no aliphatic GLSs such as GR or GIB; for this reason, neither SFN nor IB was expected in the samples (data not shown).

Dietary GLSs, as ITC precursors, remain key to the current view of how a diet rich in Brassica vegetables is associated with a decreased risk of cancer, particularly for cancers of the bladder, colon and lungs [37]. The analytical methods presented here may assist in the analysis of GLS intake and bioavailability (through the study of ITCs and related metabolites). Furthermore, this study estimated SFN and related metabolites (-CYS, -NAC, and -GSH) separately in the same run and with a short analysis time, and found that most SFN was conjugated rather than free, showing that SFN metabolism takes place in the gastrointestinal lumen during absorption. This is in agreement with previous results [42].

In addition to the type of sample selected to analyze ITC bioavailability, the choice of the methodological procedure, i.e. UPLC-QqQ-MS/ MS, used for this type of analysis constitutes an essential decision. The application of this method to the qualitative and quantitative determination of GLSs, ITCs and related metabolites, as well as the robustness and reproducibility of the analytical platform used exhibited utility for further assays focused on the characterization broccoli according to several factors.

\section{CONCLUSIONS}

In conclusion, we can say that the ITC concentration depends of the cultivar, the plant organ and sample processing. ITCs and their naturally occurring glucosinolate precursors are consumed as part of a diet rich in cruciferous vegetables such as broccoli. In this sense, we can conclude that cv. 'Naxos' produced higher ITC levels of all the studied ITCs and metabolites in plant organs and fractions; therefore, this dietary source may have enhanced chemopreventive properties. The freeze-dried plant samples grown for this study showed higher ITC concentrations than the commercial samples. Moreover, higher GLS and ITC concentrations were found in the initial steps of the digestion process, followed by the concentrations found in the dialyzed samples, and finally in the non-dialyzed samples. These findings demonstrate the highest bioaccesibility and liberation of these compounds under gastrointestinal conditions from the original plant tissue, and also showed, on the other hand, a decrease in the GLS and ITC concentrations with the digestion process. Therefore, the concentration of ITCs decreased in accordance with the content of precursor GLSs. Measurement of ingested GLSs, particularly the major GLSs that give rise to cancer-preventive ITCs, will assist in quantifying the GLS input in dietary surveys and cancer chemoprevention studies. However, additional research concerning the availability of bioactive compounds in humans is necessary.

Acknowledgments. This work was funded by the Seneca Foundation - Regional Agency for Science and Technology of the Autonomous Community of the Murcia Region through Project Ref. CARM 08753/PI/08. Part of this work was also funded through the Excellence in Research funds of the Food Science and Technology Group, grant number 04486/GERM/06. The authors would also thank Dr. David J. Walker for correction of the English language and style.

\section{REFERENCES}

[1] D. T. Verhoeven, R. A. Goldbohm, G. van Poppel, H. Verhagen, Epidemiological studies on Brassica vegetables and cancer risk, Cancer Epidem. Biomar. 5, 733-748 (1996).

[2] J. V. Higdon, B. Delage, D. E. Williams, R. H. Dashwood, Cruciferous vegetables and human cancer risk: Epidemiologic evidence and mechanistic basis, Pharmacol. Res., 55, 224-236 (2007).

[3] D. A. Moreno, M. Carvajal, C. López-Berenguer, C. García-Viguera, Chemical and biological characterisation of nutraceutical compounds of broccoli, J. Pharmaceut. Biomed., 41, 1508-1522 (2006). 
[4] J. W. Fahey, A. T. Zalcmann, P. Talalay, The chemical diversity and distribution of glucosinolates and isothiocyanates among plants, Phytochemistry, 56, 5-51 (2001).

[5] E. H. Jeffery, M. Araya, Physiological effects of broccoli consumption, Phytochemistry, 8, 283298 (2009).

[6] J. D. Clarke, K. Riedl, D. Bella, S. J. Schwartz, J. F. Stevens, E. Ho, Comparison of isothiocyanate metabolite levels and histone deacetylase activity in human subjects consuming broccoli sprouts or broccoli supplement, J. Agr. Food Chem., 59, 10955-10963 (2011).

[7] A. M. Bones, J. T. Rossiter, The myrosinase-glucosinolate system, its organisation and biochemistry, Physiol. Plantarum, 97, 194-208 (1996).

[8] C. D. Grubb, S. Abel, Glucosinolate metabolism and its control, Trends Plant. Sci., 11, 89-100 (2006).

[9] T. A. Shapiro, J. W. Fahey, A. T. Dinkova-Kostova, W. D. Holtzclaw, K. K. Stephenson, K. L. Wade, L. Ye, P. Talalay, Safety, tolerance, and metabolism of broccoli sprout glucosinolates and isothiocyanates: A clinical phase I study, Nutr. Cancer, 55, 53-62 (2006).

[10] L. Mi, Z. Xiao, B. L. Hood, S. Dakshanamurthy, X. Wang, S. Govind, T. P. Conrads, T. D. Veenstra, F. L. Chung, Covalent binding to tubulin by isothiocyanates. A mechanism of cell growth arrest and apoptosis, J. Biol. Chem., 283, 22136-22146 (2008).

[11] H. Yuan, S. Yao, Y. You, G. Xia, Q. You, Antioxidant activity of isothiocyanate extracts from broccoli, Chinese J. Chem. Eng., 18, 312-321 (2010).

[12] R.F. Mithen, Glucosinolates and their degradation products, Adv. Bot. Res., 35, 213-262 (2001).

[13] M.W. Farnham, J. W. Fahey, K. K. Stephenson, Selection for floret glucoraphanin concentration among inbred Broccoli, HortScience, 34, 448 (1999).

[14] S. Pérez-Balibrea, D. A. Moreno, C. GarcíaViguera, Genotypic effects on the phytochemical quality of seeds and sprouts from commercial broccoli cultivars, Food Chem., 125, 348-354 (2011).

[15] N. Baenas, D. A. Moreno, C. García-Viguera, Selecting sprouts of Brassicaceae for optimum phytochemical composition, J. Agr. Food Chem., 60, 11409-11420 (2012).

[16] G. R. de Nicola, M. Bagatta, E. Pagnotta, D. Angelino, L. Gennari, P. Ninfali, P. Rollin, R. Lori,
Comparison of bioactive phyrochemical content and release of isothiocyanates in selected brassica sprouts, Food Chem., 141, 297-303 (2013).

[17] F. Vallejo, A. Gil-Izquierdo, A. Pérez-Vicente, C. García-Viguera, In vitro gastrointestinal digestión study of broccoli inflorescence phenolic compounds, glucosinolates, and vitamin C, J. Agric. Food Chem. 52, 135-138 (2004).

[18] A. Martinez-Sanchez, A. Allende, R. N. Bennett, F. Ferreres, M. I. Gil, Microbial, nutritional and sensory quality of rocket leaves as affected by different sanitizers, Postharvest Biol. Tec., 42, 86-97 (2006).

[19] L. Rask, E. Andréasson, B. Ekbom, S. Eriksson, B. Pontoppidan, J. Meijer, Myrosinase: gene family evolution and herbivore defense in Brassicaceae, Plant Mol. Biol., 42, 93-114 (2000).

[20] N. Clossais-Besnard, F. Larher, Physiological role of glucosinolates in Brassica napus. Concentration and distribution pattern of glucosinolates among plant organs during a complete life cycle, J. Sci. Food Agr., 56, 25-38 (2006).

[21] G. Padilla, M. E. Cartea, P. Velasco, A. de Harob, A. Ordás, Variation of glucosinolates in vegetable crops of Brassica rapa, Phytochemistry, 68, 536545 (2007).

[22] M. Francisco, M. E. Cartea, P. Soengas, P. Velasco, Effect of genotype and environmental conditions on health-promoting compounds in Brassica rapa, J. Agr. Food Chem., 59, 2421-2431 (2011).

[23] S. Piacente, V. Carbone, A. Plaza, A. Zampelli, C. Pizza, Investigation of the Tuber Constituents of Maca (Lepidium meyenii Walp.), J. Agr. Food Chem., 50, 5621-5625 (2002).

[24] J. M. Abercrombie, M. W. Farnham, J. W. Rushing, Genetic combining ability of glucoraphanin level and other horticultural traits of broccoli, Euphytica, 143, 145-151 (2005).

[25] J. W. Fahey, Y. Zhang, P. Talalay, Broccoli sprouts: An exceptionally rich source of inducers of enzymes that protect against chemical carcinogens, Proc. Natl. Acad. Sci. U.S.A., 94, 10367-10372 (1997).

[26] A. F. Brown, G. G. Yousef, E. H. Jeffery, B. P. Klein, M. A. Wallig, M. M. Kushad, J. A. Juvik, Glucosinolate profiles in broccoli: Variation in levels and implications in breeding for cancer chemoprotection, J. Am. Soc. Hortic. Sci., 127, 807-813 (2002).

[27] M. W. Farnham, K. K. Stephenson, J. W. Fahey, Glucoraphanin level in broccoli seed in largely determined by genotype, HortScience, 40, 50-53 (2005). 
[28] C. S. Charron, A. M. Saxton, C. E. Sams, Relationship of climate and genotype to seasonal variation in the glucosinolate-myrosinase system. II. Myrosinase activity in ten cultivars of Brassica oleracea grown in fall and spring seasons, J. Sci. Food Agr., 85, 682-690 (2005).

[29] T. Oliviero, R. Verkerk, M. Dekker, Effect of water content and temperature on glucosinolate degradation kinetics in broccoli (Brassica oleracea var. italica), Food Chem., 132, 2037-2045 (2012).

[30] R. M. Bheemreddy, E. H. Jeffery, The metabolic fate of purified glucoraphanin in F344 rats, J. Agr. Food Chem., 55, 2861-2866 (2007).

[31] C. C. Conaway, J. Krzeminski, S. Amin, F.L. Chung, Decomposition rates of isothiocyanate conjugates determine their activity as inhibitors of cytochrome p450 enzymes, Chem. Res. Toxicol., 14, 1170-1176 (2001).

[32] R. Dominguez-Perles, S. Medina, D. A. Moreno, C. García-Viguera, F. Ferreres, A. Gil-Izquierdo, Bioavailability of glucosinolates and isothiocyanates from $1 / 2$ and 1 servings of broccoli sprouts by a new UHPLC/MS/MS, Food Chem., In Press, (2013).

[33] M. C. Rodríguez-Hernández, D. A. Moreno, M. Carvajal, C. García-Viguera, M. C. Martínez-Ballesta, Natural antioxidants in purple sprouting broccoli under Mediterranean climate, J. Food Sci., 77, C1058-C1063 (2012).

[34] M. Wielanek, H. Urbanek, Glucotropaeolin and mirosinase production in hairy root cultures of Tropaeolum majus, Plant Cell Tiss. Org., 57, 3945 (1999).

[35] M. Traka, R. Mithen, Glucosinolates, isothiocyanates and human health, Phytochem. Rev., 8, 269-282 (2009).
[36] J. D. Hayes, M. O. Kelleher, I.M. Eggleston, The cancer chemopreventive actions of phytochemicals derived from glucosinolates, Eur. J. Nutr., 47, 73-88 (2008).

[37] P. J. Thornalley, IARC Workgroup, Cruciferous vegetables, isothiocyanates and indoles, IARC Handbook of Cancer Chemoprevention, 9, 1-261 (2004).

[38] T. A. Shapiro, J. W. Fahey, K. L. Wade, K. K. Stephenson, P. Talalay, Human metabolism and excretion of cancer chemoprotective glucosinolates and isothiocyanates of cruciferous vegetables, Cancer Epidem. Biomar., 7, 1091-1100 (1998).

[39] M. C. Myzak, P. A. Karplus, F. L. Chung, R. H. Dashwood, A novel mechanism of chemoprotection by sulforaphane inhibition of histone deacetylase, Cancer Res., 64, 5767-5774 (2004).

[40] A. Seow, C. Y. Shi, F. L. Chung, D. Jiao, J. H. Hankin, H. P. Lee, G. A. Coetzee, M. C. Yu, Urinary total isothiocyanate (ITC) in a populationbased sample of middle-aged and older Chinese in Singapore: relationship with dietary total ITC and glutathione S-transferase M1/T1/P1 genotypes, Cancer Epidem. Biomar., 7, 775-781 (1998).

[41] J. M. Cramer, M. Teran-Garcia, E. H. Jeffery, Enhancing sulforaphane absorption and excretion in healthy men through the combined consumption of fresh broccoli sprouts and a glucoraphanin-rich powder, Brit. J. Nutr., 13, 1-6 (2011).

[42] S. Agrawal, B. Winnik, B. Buckley, L. Mi, F. L. Chung, T. J. Cook, Simultaneous determination of sulforaphane and its major metabolites from biological matrices with liquid chromatography-tandem mass spectroscopy, J. Chromatogr. B., 840, 99-107 (2006). 